\title{
Assessing Land Tenure Environment as a Catalyst in Urban Conflict - The Case of Egypt
}

\author{
M. Raslan
}

\begin{abstract}
- the paper seeks to assess land tenure environment of Egypt in an attempt to discover policies and laws that can be customized to resolve conflicts resulted from land tenure.

Systematic review of Data on land tenure environment of Egypt, land access, land governance and tenure security, the actors involved in these processes, their roles, the land tenure related challenges they face and measures that can be taken to address these challenges was collected at country level.

In the context of Egypt, Access to land is deemed with obstacles confronting beneficiaries and legal procedures that uncover dispute. Land governance institutions are drained and inefficient, often registering land improperly, causing disagreements on land ownership while competing to gain power of administrated land. Land tenure insecurity is encouraged because of vulnerable land rights and the mechanisms in place to make claims over land. By investigating the land tenure environment, conclusions could be drawn on how to improve the systems so that they can be used as development tools that decrease the probability of conflict to happen.
\end{abstract}

Index Terms-Access to land, Land governance, Land tenure Environment, Tenure security, Urban conflict.

\section{INTRODUCTION}

Research done on urban developments in Egypt shows there is a link between land tenure and physical and spatial characteristics of developments. The UN-Habitat (2007)[1] in their research on the condition of informal settlements in Egypt identified land tenure systems as one of the factors contributing to informal settlements in the country. The report highlighted unclear tenure relations where multiple interests on one piece of land held by different people as a major limitation to development control and direct cause for urban conflict.

Johannsen (2008) [2] investigated informal mechanisms of accessing land in informal settlements in Cairo. His study focused on behavior patterns of key actors involved in land access from obtaining information on plot availability, setting of parcel boundaries to registration of rights. Findings of this research showed that informal processes of accessing land in Cairo are not disordered but are regulated by informal rules which draw from existing legal policies and customary rules. Yet, these policies are the main reason for conflict around multiple areas in Cairo causing the city to be contested.

Although previous research on land tenure and urban developments in Egypt discussed above highlight uncertainty over existing tenure relations as a burden for land use planning,

M. Raslan is with the Architecture Department, Faculty of Engineering , Alexandria University, Egypt they do not illustrate how this has led to urban conflicts which leads a city to be contested. This research by examining land tenure environment processes under different land tenure systems clarifies the roles, interests, strategies and interactions of actors in these processes providing insight on the stage of the land and property development process in which informality occurs. The output of this research would be useful to (a) Institutions responsible for land management in Egypt (b) bodies charged with management of urban developments in Egypt (c) Civil Society Organizations undertaking various interventions on informal urban developments in Egypt (d) Institutions charged with land conflict resolution measures.

\section{MethodOLOGY}

Qualitative methods was applied in collecting the data needed to adequately address the research questions. Although quantitative methods were relevant, they weren't applied due to the lack of resources and security permissions.

Data relevant to the three land tenure environment components was collected mainly through literature review. Review of relevant literature also aided in the identification of bodies involved in land tenure environment processes under the land tenure systems in Egypt from which information significant to this study was pursued through expert interviews.

Responses obtained from expert interviews were transcribed and the questions as set in the interview guide and the additional questions that came up during interviews matched with the responses given [3].

\section{ACCESS TO LAND}

The lack of systematic land registration has become an increasing problem in Egypt. Approximately one hundred people are killed annually in Egypt due to land conflicts [4]. The problem has been on the increase because of the fast growing population in Egypt. There are more than 95 million Egyptians in Egypt today and this number is expected to reach 100 million by 2025 [5]. This growth has necessitated the development of unused land. As these extensions, especially in villages or rural areas, were not implemented according to a plan followed by the state they depended on society and individuals to arrange them amongst themselves. Therefore, clashes due to a conflict of interests have been increasing and have become hard to control. Furthermore, the population growth (Egypt has a population growth of 2.51 percent per year [5] which creates additional problems because of the limited cultivatable land in the country. More and more people, both poorer people forced to move to 
the border of the old inhabited land because of the limited land available for housing in the old areas, and investors and spectators who have seen this development as a way to make money, have felt compelled to move from registered old land to the non-registered newly reclaimed desert areas. This has meant an increase in the number of disputes about desert land that is reclaimed or that people want to reclaim.

The most imperative reason for the lack of land registration is due to the maze of bureaucratic procedures a person has to go through if he wants to own his land officially. In order to officially own a piece of land in the newly reclaimed areas in Egypt one has to go through 24 procedures, in 13 different offices, involving three different ministries [6]. Further, the formulation of urban and rural areas is unclear in the law, which has led to some problems in the areas close to the desert. Law no. 3 of 1982 illustrates the lack of formulation in the law by giving only a blurred definition of urban areas. This has led to brokers escaping both rising prices in the cities and laws directed toward the cities' urban areas by moving to the rural areas. There is a general lack of cooperation between the different authorities dealing with the issue which opens up the possibility of conflict and violations of laws as well. Experts have pointed out that there is a big problem concerning under staffing, lack of facilities and equipment (available maps are often outdated) in the authorities involved with landownership [7]. Each governorate in Egypt experiences an average of 9000 land violations every year. At the same time, the average number of employees in a governorate dealing with this issue is 50 people [8]. This fact shows how difficult it is for authorities to handle the large number of violations. The employees' salary is very low and this makes it even harder to keep experienced officials or keep out corruption or attract a new work force.

Acquiring land or transferring it in Egypt is not an easy or simple procedure. On the contrary it is a very long and complicated process. To acquire a property legally there are many procedures that should be followed. Acquiring private property is the easiest among all forms of property. While acquiring state Public Domain is completely forbidden and any kind of squatting on it cannot be registered by the governmental authorities. The state Private Domain can be legalized in case of squatting but with very difficult and strict procedures.

\section{A. Legalizing of land transmission "Non Built Property"}

The procedure is really complicated and time consuming. The owner of the property should prepare a file including application form, a primary contract and receipt of property tax to the Real Estate Registry [2]. Afterwards, the Real Estate Registry investigates the file and send it to the survey authority that send a personnel for a field visit to check the exact location of the property, the boundaries and the total surface area and if there is an existing conflict about the land or its boundaries [7].

\section{B. Legalizing of land transfer "Built Property"}

To register a built property, the applicant for ownership should ensure two main things: (a) the seller should be registered as the last owner of the land in the Real Estate Registry and (b) the building is in the construction permitted building zone. If the two conditions are met the applicant for ownership follow the same procedures as the preceding case [2]. While if not met, the property can never be registered. In the case of private property, the buyer and the seller must sign a primary contract, while signatures observed by two witnesses. The primary contract contains land's details, for example: parcel size, parcel location and sale price. For the contract to be considered officially legal, it should be registered in the Real Estate Registry [6 ]. If the property is a state Private Domain, it gets more complicated and hard as the seller in this case is the state and it takes a lot of time to finish this transfer, according to the Egyptian Center for Economic studies, this procedure can last for 435 waiting days and costs nearly 20,000 L.E [11].

\section{Formalization of Sales Contract}

There are two tricks that beneficiaries use to get tenure security. The first is testimony of signature. In this case, both the buyer and the seller sign a contract. Afterwards, the seller appears before the court; requiring confirmation for his signature. The judge gives him a testimony after verifying his signature, without giving attention to the terms of the contract. The second trick is validation of purchase date. In this case, the buyer after signing the contract, approaches the local Real Estate Registry to confirm the date of sale. According to an interview conducted by the author with a lawyer [12], these papers are not title deeds and do not secure tenure. Yet, they can be used afterwards in the court along with other documents to strengthen the applicant for ownership situation in the court to achieve tenure security and prevent forced eviction.

\section{Summary}

There is insufficient law enforcement in Egypt. The Egyptian authorities have for decades tried to implement legal land registration without much success. Most of the conflicts and the violations over land are due to the lack of implementation and monitoring of laws. Although the state has criminalized encroachment in most places in Egypt, the practice continues and even increased after implementation of Law no. 134, 2006, which prohibited any further acquirement of land through encroachment after August 2006 [6]. The continuing increase of the practice was partly due to people trying to gain as much land as possible before the activation of the law.

The state's reduction of registration fees has not encouraged people to register their land. The law gives the right to holders of customary or primary contracts to have legal possession of their land, although not through full ownership. As long as customary contracts are partly legal, there is little chance that people will start to register their land.

The state is trying to be watchful and there are efforts, such as the establishment of the National Centre for Planning State Land Uses which has been tasked with stopping land violations, deal with the overwhelming use of customs and traditions and synchronize actions between the diverse authorities. These efforts, so far, have proven to be insufficient at putting an end to local traditional practices and defending citizens' rights. Accordingly, we have to investigate the actors and authorities involved in the land governance, which will be discussed in the next section. 


\section{LAND GOVERNANCE}

The context of Egypt confronts simple dichotomies with regards to land (formal and informal, legal and illegal), along with a number of critical dimensions. Firstly, unregistered property represents roughly $58 \%$ of all properties in the country [9]. Secondly, the illegal mainly overrides the legal in capacity and reach. Illegal routes to accessing land and housing have become the norm for the majority of citizens rather than the exception as mentioned before; nonetheless, land classified by the government as "informal" still bears negative implications [13]. These negative implications are used to justify the planned developments for the elite at the expense of the majority of urban citizens and support policies of self-reliance policy declared by Sadat in the late seventies. These declared and implemented policies by Sadat, lasted through Mubarak's authority, and were used to give explanation for the failure to provide services to large numbers of Egypt's citizens [14]. Intense and evident centralization of decision making about land issues, resulted in declining investments in planning at the local level, as nearly all decisions about planning and land were made and executed by ministries. Informal areas are thus "a consequence of an authoritarian political order as well as embedded in the informal control tricks used by Egyptian governments to support their rule"[14]. In the meantime, the formal is also not remarkably well regulated. Bribery and Favoritism corruption at the lowest levels of administration cause a formal land registration system where consistently applied legal and administrative enforcement is the abnormality rather than the rule [9].

The contrast between "formal" and "informal" areas is critically confusing in Egypt where informal areas overshadow in scope the formal, in addition to "hiding questions of power, responsibility and social relations"[15]. In fact, the distinction held by elites over which neighborhoods are formal and which are informal would be lost on most Egyptians who typically consider informal settlements to mean only the poorest and less livable non planned areas, an extensively smaller category than the legal description which includes all unregistered property or 58\% [9]. Additional examples which demonstrate the limits of this contrast between formal and informal, are the cases where the state becomes involved in acts linked with the informal, such as squatting on a piece of land [16].

\section{A. Land Governance Institutions Analysis}

Egypt suffers from a vulnerable managerial system, due to "extreme centralization, lack of transparency, and communication collapse between the authorities and citizens" [9]. Up until the revolution of 25 January, decisions were in the hand of a preferred group of individuals, all of them were affiliated with the National Democratic Party. The diversity of institutions that exist, many with overlapping authorizations that contest against each other, compete for access to land as a favoritism resource [17]. Currently, there are over 30 different national and local government organizations involved in some aspect of the planning and management of Greater Cairo [18]. Policy-making and decisions are generally commanded by the central government, although it is not invulnerable to divisions itself. Governance in Egypt tends to be driven more by the influence of specific individuals than institutions, with the latter being used as a means for the development of favoritism systems [18].In the forthcoming section, we will discuss issues of competing between governance institutions and the conflict that results from them.

\section{i. Ministries}

Central ministries are dominant actors in relation to land governance and urban planning. However, the dominance of the central government's control coexists with a general mismanagement, plain ineffectiveness and basic disorganization that create the conditions for corruption and favoritism systems to thrive. An important factor that enrage this situation is the competition of power among ministries. Several bodies have conflicting interests, inessential authorization, and fail to coordinate with each other [19]. This has resulted in a complicated and often contradictory coordination between urban planning and land management. In particular, ministries compete for control over land that is not privately owned, this being mostly desert land. The Ministry of Petroleum, for example, may search for oil on a particular piece of land and then claims control of the land in addition to the resource below it [18].

The Ministry of Housing has a particularly strong role in urban governance, yet rarely coordinates with the other ministries that prepare urban and regional development studies and plans. The Ministry of Planning and Local Development prepares regional development plans and studies and the Ministry of Tourism prepares coastal zone management plans. All plans, whether at the national, regional or local level, must be assessed and approved by the Ministry of Defense and Military Production. The Ministries of Agriculture and Land Reclamation, Ministry of Religious Endowments 'Al-Awqaf' and Ministry of Culture through the Egyptian Authority for Antiquities also directly affect the decision making in urban planning in Egypt [20].

\section{ii. The Military}

The military is one of the generally dominant Egyptian institutions. During Naser era, former military officers were given most policy making critical positions of the government. In relation to land, their impact can be traced back to their principal role in the reclamation of desert [22] and nowadays can be seen infiltrating land market and the legal system.

The military depends on real estate for a considerable fraction of their income - often informally selling uncultivated agricultural lots. As obvious throughout the creation of the New Cities, they also sell vast areas of the desert conserved for official use [18]. In addition, they have raised their dominance to manipulate major infrastructure projects as well. In the early nineties, for example, the Ring Road route was specially directed two kilometers to the east of Cairo through the desert for "military reasons", with a western arc in this road being established on agricultural land on Giza's external edge [23]. Finally, the Egyptian military handles a precise task in the legal system with respect to land. When authorities became more determined to stop building on agricultural land, they approved 
a law in 1996 that made such action a criminal offense to be handled in military courts [24].

\section{iii. General Organization for Physical Planning (GOPP)}

The GOPP is one of the most crucial actors responsible for urban planning and governance in Egypt. Testimony to its importance is the fact that it is contained within the Ministry of Housing and receives cooperation from UN HABITAT. It is responsible for preparing urban plans (mostly master plans) for major cities and acquired its distinction in particular with connection to the Greater Cairo Master Plan, or else recognized as "Cairo 2050" which the GOPP leads [18]. In the context of the recent law 119/2008, they are presented with the liability of drawing local strategic plans for the governorates in approaches that are suitable to their potentials and resources. GOPP has produced multiple of strategic plans for Egyptian Governorates, cities, small cities, and outlining urban cordons for rural communities. These plans now mostly stand as a sorrowful reminder of the disparity between plans and actions dilemma to the Egyptian administration.

\section{iv. Informal Settlement Development Fund (ISDF)}

An institution under the authorization of the Egyptian Prime Minister, ISDF works with yearly resources of 500 million Egyptian pounds, directly on popular housing areas which are regarded as hazardous [18]. In September 2008, a grave rockslide at Al-Doweyqa occurred, which killed at least 120 people in Mansheyet Naser, a considerable informal area in Cairo. Consequently, the ISDF has been classifying Egypt's informal areas in relation to their evaluation of the level of hazard challenging local inhabitants, whether from natural risks like rockslides or any other threats to their lives and health.

Despite the fact that exposure to natural risks are realistic, the issue of safety might be used to justify manipulative plans or policies and in extreme scenarios evict poor people living on precious real estate. ISDF develop plans which then be proposed to the central government to be accepted before being passed on to the local governorate for execution. The outcomes of such evictions on the lives of those influenced are, in several cases, not sufficiently taken into account. Yet, ISDF argues that the civil society significantly contributes in the ISDF's information gathering or decision making processes [16].

\section{v. Governors and Governorates}

Governors have the level of a minister, are selected directly by the president and are seen as his direct delegates holding stately authority. At one point in the past decade, 23 out of 26 governors were from the military [18]. This is indicative of the general attitude of the state of Egypt towards the majority of its citizens, which are viewed by the government as a security problem. In Egypt, the state's most important goal is to sustain stability and avoid social unrest, instead of providing services and planning for development.

There is one main feature in which the authority of governors is lower to that of ministers and which restricts their ability to function: governorates rely on the central government for $80 \%$ of their resources. The rest is collected from fees, a very small portion of which can be used at the governorate's freehand [9]. As a result of these limitations, governors often use whatever influence they have as direct representatives of the president to -for example- initiate land development projects in partnership with private sector financiers.

\section{vi. National Centre for Planning State Land Uses (CPSLU)}

So far, the CPSLU has prepared maps for investment opportunities. Nevertheless, some areas were included in the map without scientific research and the CPSLU concluded that the maps are thus unsuitable for the determined purpose of outlining how the land could be used at this time.

One of the main problems in controlling land is that local authorities consider land violations outside the borders of the governorate out of their control. However most people do not ask for permission from the authorities to use land, thus most buildings and houses that are established are illegal.

The consequences of encroachment practices are not only the bloody conflicts but also the acquisition of almost free plots of land which can be sold to citizens for huge sums of money which is considered wasting of public wealth.

Further the CPSLU is supposed to regulate the conflicts between the governorates related to land. This is quite complicated as the most recent maps available to describe the rural extensions in the villages and the cities date from 1938 [7] Thus there is a huge gap between the reality and the maps. This is because of the changes that have happened in some villages, which have become cities now and have extended to the borders of other cities. The CPSLU has not yet followed these developments that seem to take place faster than the state can monitor them. In order to achieve faster monitoring in the future, the center will need to harmonize all the efforts of the concerned authorities together.

\section{B. Legal Framework}

In addition to understanding the actors involved in and affected by the current system of land governance in Egypt, it is vital to study the legal aspect of the system within which they operate and explore who gains or loses under current structures. Legal context of housing regulation is a remarkable tool in investigating the laws that govern land, as rent control laws have played a dominant role in obstructing the construction of affordable housing, as well as the restoration of present housing supply. This, in turn, generates a barrier to the land property accessibility. The pause in construction because of the Second World War intensely raised rent prices in Egypt. Accordingly, The central government established rent control laws in 1952, 1958 and 1961 in attempt to vanish this phenomena. In 1952, this lowered rent by $38 \%$ of its 1945 value to guarantee affordability and stopped it at that rate, with few amendments in subsequent years [18]. Hence, the private sector departed the worthless rental housing market, and private owners were unwilling to preserve existing housing stock. As a result, Housing settlements declined and deteriorated [22]. More notably, these rent control laws are example of a law associated with land governance that does not help those it is meant to serve. Although the rent control laws remained inhibiting the housing market today, an answer is not as plain as lifting rent control, as this could direct to the financial displacement of tenants incapable to afford market prices. Not only is there a lack of private sector investment in housing, but following the 1967 war there was also a major decline in public investment in 
housing, and this led to an additional increase in informal development. In the late sixties, informal areas started to inflate rapidly on agricultural land [20].

An anticipated $36 \%$ of housing stock in Cairo and Alexandria is immobile under rent control. Yet, Law 4. of 1996 unchained the rental market for the recently built [15] What worsened this situation, under Anwar Sadat, Law Number 178 for Egyptian Land Reform - which increased equitable access to land and reallocated $12 \%$ of Egyptian land - was abolished and the number of landless people in time increased [25].

Informal areas continuously expanded with the simultaneous issues of a low supply of affordable housing and a decrease in options for low and middle income Egyptians. In 1974, Extra burden on the housing market emerged, when Sadat declared the state strategy of constructing desert cities throughout Egypt [9]. The policy can be traced back to the revolution of 1952, when Naser was confident of the idea that mega scale reclamation of the desert was the means to sweep away Egypt's intensely undesirable huge population densities [22]. The policy focused public investment particularly in new cities but with little remaining for housing supply in existing cities, resulting in an uneven advancement in new cities with insufficient infrastructure in initial phases and eventually, vacancy [20]. Again, this added to the housing crisis, which sequentially led to the intensification of informal areas.

\section{Summary}

Land has served as a currency of favoritism and power distribution among authorities in Egypt. This reality demonstrates itself in different authorities conflicted interests, in competition among national ministries, and in state-society relations, as seen in recent property scandals. Governance over land in Egypt is characterized by competing views. These competing views have dominated official institutions, leading to the creation of alternative pathways and systems that Egyptians navigate in an attempt to access land, and resulted in an elite urban-planning vision, situated in a previously oppressive governance system which ironically privileged stability and "security" over providing for the needs of the majority of the population. This system in Egypt contributed to a serious legitimacy crisis. Consequently, in the next section we will explore how this legitimacy crisis affected tenure security.

\section{TENURE SECURITY}

Tenure security causes a dilemma to most of the developing countries for decades. Nearly $60 \%$ of the developing countries urban residents lack legal documents for the tenure security [26]. Universal Declaration of Human Rights stated that suitable housing is essential to achieve a satisfactory standard of living [27]. The right to adequate housing should be enforced with the provision of legal access to land, effective use of land and protection from forced eviction that is obliged by the international law [28]. Legal or secure access to land is the chance of people to inhabit or use the land either permanently or temporarily as a shelter or for economic activities. Secure access to land motivates people to develop economic activities and invest in land.

\section{A. Tenure Security in the Egyptian law}

In 2008, the parliament approved the 'Unified Building Law no. 119/2008'. The law deals with different aspects; urban planning, urban landscape, building construction and conservation of real estate resources [29]. According to the mentioned law there is no term named 'Informal settlements'. Yet, it is still present but in a different term which is 'Unplanned areas'. The ISDF later in 2008, changed the terms - slums, informal settlements into 'Unsafe areas' and 'Unplanned areas' [18]. Thus according to the Egyptian law, the term 'informal settlements' does not exist. The first section of the 'Unified Building Law no. 119/2008' includes several definitions that are used from now on in Egypt. The most important of them to the context of tenure security are the following [29]:

Re-planning areas/ Redevelopment areas: areas that need development and renovation; and it is identified in the strategic plan of the city or village.

Unplanned areas: areas that showed in disobedience to urban and planning regulations; and they are recognized by the official strategic plan of the village or the city.

Residential cluster: a group of residential, services and recreational buildings according to the official detail master plan.

However, the Egyptian legislation related to land or property makes many forms of tenure insecure, such as the law of dispossession for the public interest, or by implementing particular and exceptional legal regulations for the expropriation of specific area under excuse of national development projects. Accordingly, other legal conditions permit the state to issue administrative regulations persuasively to evict some residents of "private" property of the state, without compelling the state to provide alternatives or acquire court orders for the eviction.

\section{B. Dispossession within Egyptian law}

The cases of dispossession for public interest are most common by way of exceptional laws and regulations. Therefore, legislative reform needs to consider:

1) Codifying the private state land tenure for residents by the acquisitive prescription (1,070 informal settlements in Egypt are built on private state land);

2) Protection for the poor against land grabbing under the pretext of dispossession for public interest, and obliging the state to provide suitable alternatives and equitable compensation for those affected with a legal mechanism that provides judicial compensation.

Egyptian law related to the dispossession property for the public interest still protect articles that contradict the state's obligations to respect, protect and fulfill the human rights to property rights and adequate housing with security of tenure. However, in 2012, Egypt played an active role in the international process to adopt a set of principles on Responsible Governance of Tenure of Land, Fisheries and Forestry in the Context of National Food Security. Legal reform that aligns legal recognition, allocates tenure rights prioritizing the poor and ensuring compensations in dispossession cases, Egypt would avoid contradicting its existing obligations under international treaty law, as well as harmonize its voluntary 
commitments under applicable regional and international instruments. [30].

The new Egyptian Constitution adopted in January 2014, in its Article 63, has banned and criminalized all forms of arbitrary forced displacement without decree of limitations. However, this term "arbitrary forced displacement" is distinct from "forced eviction," and could exclude many forced eviction cases from the concept of displacement, specifically in the cases of informal settlements and marginalized areas. Article 35, which protects the property rights, does not define cases of expropriation for public interest, and does not ensure that the expropriation decision shall be issued by final judicial ruling [12].

Finally, the new Constitution recognizes some economic and social rights related to housing and land, it is not drafted with the human rights approach, leaving potential gaps in implementing current treaty obligations. These lacunae point to the need for greater efforts at monitoring and advocacy to realize, protect and fulfill housing and land rights.

\section{CONCLUSION}

The objective of this study was to investigate the role of the land tenure environment in land conflict situations. It explained how although the structures for land tenure development programs, administrations and legal policies are in place, they can fail to act as development tools and can actually generate conflict. An extensive review of the literature found that there are many ways in which the causes of land conflict can be classified, but they all fit within three general categories: access to land, land governance structures, and tenure security. Access to land can be addressed in the developing environments through laws reforming efforts in which state led and community led approaches are used to increase the accessibility of land to landless individuals, as well as law enforcing regulations related to legal access. Land governance required the formation of institutions to properly register and record properties while ending the competency over land between authorities. Lastly, tenure security relied on the acknowledgment of land rights. Integrated together, these things form up the land tenure environment. The main purpose of this research was to show that the land tenure environment can play a vital role in developing strategies for land tenure. To do so, it was crucial to explore the value of the land tenure environment in addressing the issues that often lead to conflict. The hypothesis is made that the more effective the environment, the greater its ability towards acting as a development tool. By investigating the land tenure environment, conclusions can be drawn on how to improve the systems so that they can be used as development tools that decrease the probability of conflict to happen. This paper focused on Egypt due to its history of high rate of land tenure conflict together with its dependence on land for economic growth. In many other countries, land tenure conflicts either appear in the outcome of other profound conflicts.

This study can be expanded in several ways to fully understand the relationship between the land tenure environment and land conflict, where a comparative study could be conducted between various land tenure environments in different countries and how policies were reformed in order to vanquish land conflict from its roots.

\section{ACKNOWLEDGMENT}

The researcher would like to show his sincere gratitude to Prof. Hany Ayyad for his guidance throughout the research. Additional thanks to all the interviewees that helped in collecting more official imperative data.

\section{REFERENCES}

[1] UN-Habitat. (2007). Global Reports on Human Settlements 2007: Enhancing Urban Safety and Security. http://www.unhabitat.org/content.asp?typeid=19\&catid=555\&cid=5359 1993.

[2] Johannsen, A. T. (2008). Landownership disputes in Egypt. Cairo: American University in Cairo Press.

[3] Kumar, R. (2005). Research Methodology: A step by step guide for beginners. London: SAGE Publications. https://doi.org/10.3758/BF03192704

[4] Mahrus, M. N. (2009, Week 22). Land registration problems in Egypt. Arab-West Report.

[5] World Bank. (2016). World DataBank: World Development Indicators. http://databank.worldbank.org/data/reports.aspx?source=2\& country=EG Y\#.

[6] Abdelhamid, E. (2017, May 10). A technical engineer - State Property Protection Agency. (M. Raslan, Interviewer) Alexandria.

[7] Ismail, A. (2017, July 10). Head of Legal department - The Egyptian Survey Authority. (M. Raslan, Interviewer).

[8] El-Hefnawi, A. I. (2005). Protecting' agricultural land from urbanization or_managing ' the conflict between informal urban growth while meeting the demands of the communities. Brasilia: World Bank Urban Research Symposium.

[9] Sims, D. (2010). Understanding Cairo- the Logic of a City Out of Control. Cairo: American University in Cairo Press.

[10] Madbouly, M. K. (2005). Egypt Case Study. Report presented at Drylands Development Center Stakeholder Workshop on Equitable Access to Land and Water Resources. Beirut: arabstates.undp.org/contents/.

[11] Alfiky, M. (2014). Community Based Security of Tenure. Stuttgart: University of Stuttgart Press.

[12] Al-Gammal, Y. (2017, September 3). Lawyer. (M.Raslan, Interviewer)

[13] Deboulet, A. (2006). The Dictatorship of the Straight Line. In Cairo Contested: Governance,Urban Space, and Global Modernity. Cairo: American University in Cairo Press.

[14] Dorman, W. (2009). Demolitions and Donors: The Problematics of State Intervention in Informal Cairo. Cairo: American University of Cairo Press.

[15] Roy, A. a. (2003). Urban Informality: Transnational Perspectives from the Middle East, Latin America and South Asia. Maryland: Lexington Books.

[16] Elyachar, J. (2005). Markets of Dispossession: NGOs, Economic Development and the State in Cairo. London: Duke University Press https://doi.org/10.1215/9780822387138

[17] Singerman, D. (2009). Cairo contested: Governance, Urban space, and Global Modernity. Cairo: American University in Cairo Press https://doi.org/10.5743/cairo/9789774162886.001.0001

[18] Hamilton, N. (2012). Land, Legitimacy and Governance in Revolutionary Cairo. New York: Columbia University Press.

[19] Ibrahim, K. (2009). Extract from a Diary: Marginal Notes on the Soft Dialectics of Historic Cairo. Cairo: American University in Cairo Press.

[20] World Bank. (2007). Analysis of Housing Supply Mechanisms.

[21] Ibrahim, B. a. (2008). From charity to social change : trends in Arab philanthropy. Cairo: American University in Cairo Press. https://doi.org/10.5743/cairo/9789774162077.001.0001

[22] Springborg, R. (1979). Patrimonialism and Policy Making in Egypt: Nasser and Sadat and the Tenure Policy for Reclaimed Land. Middle Eastern Studies, 49-62.

[23] Adriansen, H. (2009). Land reclamation in Egypt: A study of life in the new lands. Geoforum, 664-674. 
https://doi.org/10.1016/j.geoforum.2009.05.006

[24] Payne, B. D.-1. (2012). Holding On : Security of Tenure - Types, Policies , Practices and Challenges. OHCHR.

[25] United Nations. (1999). The Right to Adequate Housing. Geneva: http://www.ohchr.org/Documents/Publications/FS21_rev_1_Housing_e n.pdf.

[26] UN-Habitat. (2008). Secure Land Rights for All. Nairobi: https://www.responsibleagroinvestment.org/sites/responsibleagroinvest ment.org/files/Secure land rights for all-UN HABITAT.pdf.

[27] Egyptian Ministry of Justice. (2008). The Encyclopedia of Unified Building . Cairo, pp. 8-10.

[28] Al-Bahay, M. A.-A. (2014). Displacement by Force of Law: Security of Tenure and Legal Lacunae in Egypt. The Land and Its People, 60-65.

[29] Guadiano, S. (2005). Fractal Cartography of Urban Patterns. Cyber Geo, 22. 